\title{
DUAL BANKING: A CASE STUDY IN FEDERALISM
}

\author{
EMMETTE S. REDFORD*
}

Scholars have often commented on the inherent complexity of federal government and on the diversities within the American system. It is like a Jacob's coat, with the peculiarity being not its many colors but its many patterns and additionally the continuous laying of new patterns over the old. ${ }^{1}$ Banking provided the setting for some of the early developments in our creative federalism, ${ }^{2}$ and the arrangements for regulating banking functions since 1863 reveal peculiarities and incremental modifications in a pattern of federal-state relationships.

The peculiarities in the pattern arise from what is commonly called the "dual banking system." In a narrow sense dual banking is simply banking under two charter systems, one national and the other state, with accompanying supervision by the chartering jurisdiction. In a broader sense, however, it encompasses all the arrangements under which national and state banks are enabled to live side by side in a comprehensive system of banking regulation imposed by national and state authorities. ${ }^{3}$ In this broader sense, six features characterize the present-day dual banking system and form a distinctive pattern in American federalism.

First, an industry of national importance and one affecting interstate commerce is a subject of state regulation. Of our major industries affecting interstate commerce only insurance, oil production, and banking are subjects of significant state regulation.

Second, the regulation by the state parallels that by the national government. There is no distinction in kind, as between things national and things local in import, in the authorities over chartering and examination of banks. The national government and the state governments are, with respect to chartering and examination, doing the same things. This is an unusual feature in the federal system. It results in competitive federalism in contrast to the cooperative federalism so often described.

Third, the regulated persons can choose the jurisdiction to which they will be

A.B. I927, M.A. 1928, University of Texas; Ph.D. I933, Harvard University. Ashbel Smith Professor of Government, University of Texas.

${ }^{I}$ For discussions of varied aspects of American federalism, see W. ANderson, The Nation and the States, Rivals or Partners? (I955); G. C. S. Benson, The New Centralization (i94I); J. P. Ciark, The Rise of a New Federalism (1938); Commission on Intergovernmental Relations, a Report to the President for Transmittal to Congress (I955); D. J. Elazar, The amarican Partinership: Intergovernmental Cooperation in the Nineteenth Century United States (rg62); R. A. Goldwin, A Nation of States: Essays on the American Federai System (Ig63); R. H. Leach \& R. S. Sugg, JR., The Administration of Interstate Compacts (1959); Area and Power (A. Maass ed. 1959); Federalism: Mature and Emergent (A. Macmahon ed. I955); R. C. Martin, The Cities and the Federal. System (1965); V. V. Thursey, INterstate Cooperation: A Study of the INTERstate Compact (1953).

atably in the development of the doctrines of implied powers and of national supremacy, especially in McCulloch v. Maryland, I7 U.S. (4 Wheat.) 316 (1819).

"Former Comptroller James J. Saxon has said: "There is perhaps no term in the lexicon of bankers which has been subject to so great a variety of interpretations as 'the dual banking system.' "Address before the National Ass'n of Supervisors of State Banks, Bretton Woods, N.H., Sept. 18, 1962. 
subject. This distinguishes banking regulation from all other fields of regulation in this country. ${ }^{4}$

Fourth, there is a substantial "delegation" policy decisions-especially on branch banking but also on many other matters-by the national to the state governments. This kind of development in American federalism became familiar to American legal scholars in the late nineteenth century, as the result of national legislation on transportation of liquor into states with prohibition laws. ${ }^{5}$ It is revealed in much of our later legislation-for example, in that concerning resale price maintenance ${ }^{\mathfrak{C}}$ and regulation of labor practices. ${ }^{7}$ Yet it is doubtful whether it is as significant in any other field of legislation, except insurance regulation, ${ }^{8}$ as it is in banking legislation.

Fifth, the regulatory position of the states is being encircled and partially eclipsed by the assertion of national policy on matters affecting banking. Encirclement leaves state chartering undisturbed but confines or overrides the policy of the state-either directly by enactments having compulsory effect or indirectly by absorption of state banks into national systems by their option. Especially significant in this regard are the development of the Federal Reserve System and the provision for federal deposit insurance. State banks entering either are subject, irrespective of state laws, to national policies and to national supervision. Encirclement and reduction of the position of the state is a typical aspect of regulatory legislation in the American federal system. Also, the development runs counter to the policy of delegation or deference to state policy that characterizes much national banking legislation. Yet with respect to the Federal Reserve System and federal deposit insurance, it retains still a peculiar feature: subjection to national policy is optional for those who choose the other option for a state charter.

Sixth, cooperative relationships have developed between the national and state banking authorities. This has been necessary because of double supervision of state banks, brought about by the Federal Reserve and deposit insurance acts. In these cooperative arrangements, banking regulation reflects one of the outstanding aspects of American federalism. ${ }^{9}$ Here again, however, the developments are somewhat atypical: the coercive authority of the national government is limited by the options available to the regulated; the pivotal fact in the pattern is the abdication of government's positive power to the choice of the private party.

The ensuing pages will sketch the historical and constitutional background of the

\footnotetext{
'For discussion of this and other peculiarities of banking regulation, see Fox, Supervision of Banking by the Comptroller of the Currency, in Public Administration and Policx Formation irg (E. S. Redford ed. 1956).

"See United States v. Hill, 248 U.S. 420 (x919); Clark Distilling Co. v. Western Md. Ry., 242 U.S. 3 II (I9I7); In re Rahrer, I40 U.S. 545 (I89r).

- Fair Trade Act (Miller-Tydings Act), I5 U.S.C. \$ I (1964), construed in Schwegmann Bros. v. Calvert Distillers Corp., 34I U.S. 384 (r95I).

7Famed $\S \mathrm{I}_{4}(\mathrm{~b})$ of the National Labor Relations Act, as amended, 29 U.S.C. $\$$ I64(b) (1964).

${ }^{8}$ I5 U.S.C. $\S \S$ rorr-I5 (I964), upheld in Prudential Ins. Co. v. Benjamin, 328 U.S. 408 (1946).

${ }^{\circ}$ On intergovernmental cooperation as a historic feature of American federalism, see ELAzAR, supra
} note I. 
dual banking system, will detail the particular aspects of federal-state relationships suggested above, and will examine finally some current arguments and issues relative to dual banking.

\section{Historical and Constitutionat Aspects}

It will be useful, prior to analysis of specific functional aspects, to review a slice of history and a slice of constitutional framework with respect to the rise and survival of dual banking in our federal system.

On history, we can note three phases of development. The first period-from Hamilton to Jackson-was one of dual banking. A national bank with branches existed from I79I to I8II and again from I8I7 to $I_{3} 6$ (at which time the second Bank of the United States expired as such by obtaining a charter from the Commonwealth of Pennsylvania). During this period, which began with only three banks existing in the nation, banks were chartered in increasing numbers by the several states. The second period-from Jackson to Chase, from 1836 to 1863 -was a period of state and private banking exclusively. The third period-from 1863 to the present-is one in which dual banking has been revived and continued.

There are several aspects of the transition to a dual banking system that are worthy of note in a story of federalism. The first is that the father of the system did not intend to create it. Chase believed that a tax on state bank notes, which was enacted as he predicted in $1865,{ }^{10}$ would "root out the heterogeneous local banks," and bring their capital into the national system..$^{11}$ That the state banks survived was due to the fact, unforeseen by Chase, that deposits could replace note issuance as a source for loan capital adequate for profitable banking operations. The dual banking system resulted, therefore, from a fortuitous development in the private sector of the economy and in spite of the contrary intention and judgment of the chief proponent of the legislation that produced national banking as we know it.

Second, the national banking system that was established was patterned, as has often been true in the history of American federalism, after the system developed in the laboratories of state experience. Instead of a unified national banking system, with a single bank and branches, such as had been created under legislation of 179 I and $18 \mathrm{I} \%$, there were separately chartered, independent banking units. The influence of the antimonopoly spirit, which had given rise to charges against the first and second Banks of the United States, is obvious. The national system follows the pattern of "free banking" that had evolved in the states, thus resulting in a true parallelism between national and state systems.

Third, while, for Chase, as well as for his predecessor, Hamilton, the fiscal needs

\footnotetext{
${ }^{10}$ Act of March 3, r865, ch. $78, \S 6, x_{3}$ Stat. 484 .

11 Letter from Salmon P. Chase to T. C. Day, Feb. 5, 1863, quoted in T. J. ANDerson, Federal AND State Control of Banking 72 (1934), and in A. McF. Davis, The Origin of the National Bankeng SXSTEM 77 (IgIO).
} 
of the national government were dominant in the planning of the banking system, the survival of parallel national and state banks was due to the response of both to the needs of commerce and industry. The survival of each type of bank has been dependent upon its ability to compete with the other type in the private market for banking services.

The constitutional foundations for a dual banking system were established early in our history in one of the monumental decisions of American federalism. McCulloch v. Maryland $d^{12}$ determined, first, that the national government's constitutional authority, by the delegation of express and implied powers, extended to the creation of a national bank and the establishment of branches. It determined, second, that a state could not impair the operation of an agency so established as an instrumentality of the national government. The decision related specifically to a state tax on the bank but was broad enough to cover any other type of state interference. It was broad, also, in that it did not inhibit merely nondiscriminatory taxation but any taxation of a federal instrumentality. The constitutional foundations for a national-and thus, also, a dual-system of banking were thus established in the principles of this first Supreme Court decision relating to the scope of national power and its correlative protection.

Constitutional issues concerning state power to grant functions to banking institutions arose over the note issuance function. In Briscoe v. Bank of Kentucky (1837), it was held that state banks could issue notes, even when stock in the state bank was held by the state. ${ }^{13}$ This construction of the constitutional limitation on the power of the state to issue paper money was strong support for the kind of state banking system that existed prior to the Civil War. The effect of the decision was ultimately overcome by that in Veazie Bank v. Fenno (r869), which upheld the prohibitory tax of ten per cent on state-bank notes and thus established, through the unilateral taxing power, complete national authority over note issuance. ${ }^{14}$

McCulloch v. Maryland has been the precedent for other decisions with respect to national banks. On its authority, the constitutionality of the Banking Act of x863 was upheld..$^{15}$ The limitations on the states with respect to these banks were stated by the Supreme Court in Davis v. Elmira Savings Bank in $1896:^{16}$

National Banks are instrumentalities of the Federal government, created for a public purpose, and as such necessarily subject to the paramount authority of the United States. It follows that an attempt, by a State, to define their duties or control the conduct of their affairs is absolutely void, wherever such attempted exercise of authority expressly conflicts with the laws of the United States, and either frustrates the purpose of the national legislation or impairs the efficiency of

\footnotetext{
${ }^{12} 17$ U.S. (4 Wheat.) 316 (I819).

${ }^{18} 36$ U.S. (II Pet.) 257 (I837).

1475 U.S. (8 Wall.) 533 (1869).

${ }^{16}$ 'Farmers' \& Mechanics' Nat'l Bank v. Dearing, 9 I U.S. 29 (I875).

${ }^{10} \mathrm{x} 6 \mathrm{I}$ U.S. $275,283(\mathrm{x} 896)$. The quoted words would probably reflect more accurately the law today if or were substituted for and after the phrase "laws of the United States."
} 
these agencies of the Federal government to discharge the duties, for the performance of which they were created.

On the other hand, in the federal system local laws on many matters are applicable to national banks. On this, too, the Supreme Court early summarized the position of national banks: ${ }^{17}$

They are subject to the laws of the State, and are governed in their daily course of business far more by the laws of the State than of the nation. All their contracts are governed and construed by State laws. Their acquisition and transfer of property, their right to collect their debts, and their liability to be sued for debts, are all based on State law. It is only when the State law incapacitates the banks from discharging their duties to the government that it becomes unconstitutional.

National legislation has permitted the expansion of state functions. As early as I864 taxing authority over shares of national banks was granted to the states. ${ }^{18}$ Since then, national policy has not only allowed the application of nondiscriminatory state legislation to national banks but has adopted state policy on state banking as national policy for national banks so extensively that a separate section of this article is devoted to the subject of national deference to state policy.

State banks do not have immunity from national legislation comparable to that of national banks from state legislation. They must pay the corporate income tax; they are subject to national legislation under the commerce power; and they are subject to the exercise of Congress's monetary powers.

The question can now be raised as to whether the dual banking system has any constitutional protection. Could Congress abolish the system directly by requiring a national charter to engage in deposit banking? Or could it accomplish virtually the same thing by requiring state-bank membership in the Federal Reserve System and extending the conditions of membership or by requiring, with regulatory strings attached, deposit insurance through the Federal Deposit Insurance Corporation? Arguments of great strength can be made for an affirmative answer to either question. They would start from three premises: (I) that Congress's power to establish and protect a national banking system having been established, it is within its power to preserve the soundness and service of that system against the competition of state banking systems operating under different, often more lenient, standards; (2) that Congress has a paramount authority over the monetary system of the nation and in the exercise of this authority can impose necessary and appropriate controls over all institutions whose operations affect the volume and quality of the monetary supply; and (3) that, since banking affects the commerce of the nation, Congress has power to regulate it in all its aspects in order to make effective the national policies with respect to commerce. The larger argument, of which these are parts, is that, as a result of what our Constitution has become, Congress has the authority to use

\footnotetext{
${ }^{27}$ National Bank v. Commonwealth, 76 U.S. (9 Wall.) 353, 362 (I869).

${ }^{18}$ Act of June 3, I864, ch. I06, $\S 4$ I, I3 Stat. III, as amended, I2 U.S.C. $\$ 548$ (I964).
} 
whatever means are appropriate to maintain a healthy economy. A state charter cannot endow banking institutions with any immunity from national power that Congress chooses to exercise, and Congress has discretion to choose among appropriate means of exercising its powers, including a national charter, membership in a national banking system, or direct imposition of legislative or administrative rules over banking institutions. If, therefore, the conditions in the nation and the interests of economic groups should create political demands of sufficient force to produce an act of Congress to unify the banking structure of the nation, it is inconceivable that the Supreme Court would hold that the legislation was unrelated to the paramount purposes of the great constitutional grants of power. ${ }^{10}$ In banking, as in many other fields of legislation, what characterizes congressional choices is not encroachment on state power but nonexercise of national power.

It does not appear likely, at this point in time, that Congress will soon abolish the dual banking system, but it does appear that the degree of independence of the state banks from national controls will be determined in the forum of national politics as a result of influences brought to bear on Congress and the President.

II

\section{Dual Chartering}

The basis of the dual banking system is the issuance of charters by two jurisdictions. The charters grant the right to do business, and the chartering jurisdiction determines the conditions for receiving the charters and for doing business under them. The charter for banking rights is more than a mere grant of power to do business, as is in effect true of corporate charters generally; it is, in addition, a means of establishing a system of regulation over entry and operations.

For the states, there is nothing unique about this system. They began early in their history to grant charters and have attached to them such regulatory provisions as they desired to impose. In the early days the states guarded jealously the grant of charter privileges and limited charter rights by regulatory provisions and supervision. Free chartering of corporations-that is, chartering virtually without regulatory prescriptions-came later and did not establish itself in banking, even though there were tendencies in this direction in the initial period of so-called "free banking" prior to the Civil War.

For the national government, the system is peculiar. That government has used its power to grant charters very sparingly. It has, moreover, except for banking, not used the charter as the means of imposing a system of regulation. It has, of course, often used other forms of enabling powers-namely, licensing and certificates of

\footnotetext{
${ }^{10}$ An argument, reflected in Hopkins Fed. Sav. \& Loan Ass'n v. Cleary, 296 U.S. 315 (1935), might be based on state sovereignty and the reserved-power clause of the tenth amendment. However, little is left of the tenth amendment since United States v. Darby, 3 I2 U.S. I00 (194I), which characterized it as a "truism" and held it ineffective to curb an exercise of a granted federal power in a reasonable fashion.
} 
public convenience and necessity-in establishing regulations; but more often it has imposed its regulation on concerns already having acquired the right to engage in business from a state charter. In banking, however, the exercise of regulatory jurisdiction begins with the charter grant.

\section{A. Fluctuation in the Relative Strengths of the National} and State Banking Systems

Dual chartering has created a real dualism in banking. National and state systems for nearly a hundred years have both been strong, and vigorous competition has existed between the two systems. The relative strength of each at various times is patently revealed in Table $I$, which sets forth figures on the number of national and state banks at particular times. As Table I illustrates, the act of $r 863$ did not

TABLE I

Number of State-Chartered and Federally Chartered Banks, by Years

\begin{tabular}{l|c|c|c|c|c|c|c}
\hline \hline Year & $\begin{array}{c}\text { National } \\
\text { Banks }\end{array}$ & $\begin{array}{c}\text { State } \\
\text { Banks }\end{array}$ & $\begin{array}{c}\text { \%o } \\
\text { National } \\
\text { Banks }\end{array}$ & Year & $\begin{array}{c}\text { National } \\
\text { Banks }\end{array}$ & $\begin{array}{c}\text { State } \\
\text { Banks }\end{array}$ & $\begin{array}{c}\text { National } \\
\text { Banks }\end{array}$ \\
\hline 1864 & 508 & 1,089 & 31.8 & 1916 & 7,608 & 15,450 & 33.0 \\
1865 & 1,513 & 349 & 81.3 & 1920 & 8,157 & 18,195 & 31.0 \\
1866 & 1,644 & 297 & 84.7 & 1925 & 8,054 & 16,983 & 32.2 \\
1869 & 1,617 & 259 & 86.2 & 1930 & 7,197 & 13,582 & 34.6 \\
1870 & 1,648 & 325 & 83.5 & 1935 & 5,386 & 8,420 & 39.0 \\
1875 & 2,086 & 551 & 79.1 & 1940 & 5,144 & 9,182 & 35.9 \\
1850 & 2,095 & 620 & 77.2 & 1945 & 5,017 & 8,964 & 35.9 \\
1885 & 2,732 & 975 & 73.7 & 1950 & 4,958 & 9,046 & 35.4 \\
1890 & 3,573 & 2,101 & 63.0 & 1955 & 4,692 & 8,932 & 34.4 \\
1895 & 3,706 & 3,774 & 49.5 & 1960 & 4,529 & 8,853 & 33.8 \\
1900 & 3,871 & 4,369 & 47.0 & 1961 & 4,512 & 8,920 & 33.6 \\
1910 & 6,984 & 12,166 & 36.5 & 1962 & 4,504 & 8,924 & 33.5 \\
1915 & 7,632 & 14,598 & 34.3 & 1963 & 4,614 & 8,954 & 34.0 \\
& & & & 1964 & 4,722 & 8,988 & 34.7 \\
\hline
\end{tabular}

Source: The figures used in this table may be not be as reliable as one would ordinarily wish, since in a few instances the sources relied upon are not consistent among therrselves. Figures are given for five-year intervals (except 1905) and for additional years to phich reference is made in the text. Overall, the representation is believed to be fair. The data were collected from Jornm Coum. oN THE Ecos ourc

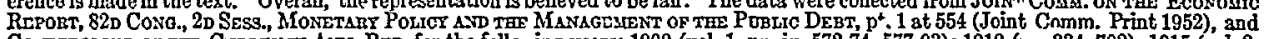

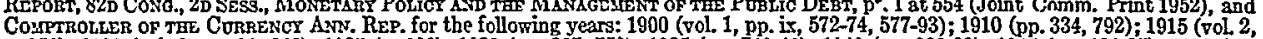
p. 951); 1920 (vol. 2, pp. 36, 840); 1925 (p. 636); 1930 (pp. 367, 752); 1935 (pp. 740-41); 1940 (pp. 222-23); 1945 (pp. 136-37); 1950 (pp. p.-55); 1955 (pp. 2, 192-93); 1960 (pp. 260-61); 1964 (p. 20).

immediately attract a large number of applications for national bank status, and most of the applications were from banks with small capitalization. A ruling of the Comptroller that state banks coming into the system could retain their names, with the prefix "national," caused state banks to come "into the national system with a rush."20 There were at the end of 1864 about half as many national banks as state banks. The enactment of the ten per cent tax on state-bank notes accelerated the conversion of state banks into national banks and threatened the extinction of state banking. The number of state banks dropped from $\mathrm{I}, 089$ in $\mathrm{r} 864$ to less than

\footnotetext{
${ }^{20} \mathrm{H}$. McCulloch, Men and Measures of Half a Century ijo (i889), quoted in Anderson, supra note $I \mathrm{r}$, at 75 .
} 
300 in I 866 and remained at that level through 1869 . In the meantime the number of national banks more than tripled, rising to and remaining at a level of more than $\mathrm{I}, 600$ in the years 1866 to $\mathrm{I} 86 \mathrm{~g}$. The state banks in this period were consistently less than one-sixth of the total of national and state banks.

The demonstration of the profitability of deposit banking and of the nonessentiality of the note-issue function led in the following years to an increasing exercise of the option for a state instead of a national charter. The increase in the percentage of state banks began in 1870 , and by 1885 they were slightly over one-fourth of the total of chartered banks. The increase continued gradually, and in 1895 the number of state banks became larger than the number of national banks. At no time since have national banks exceeded the number of state banks. The proportion of state banks continued to increase over a protracted period and in 1916 reached for the first time two-thirds of the total of chartered banks. This proportion remained fairly steady until the depression of r929. Thereafter the proportion of state banks fell somewhat. From the late I930s there were for years about nine state banks to every five national banks. It is obvious from the figures that the passage of the Federal Reserve and deposit insurance acts in 1913 and 1933, respectively, had no appreciable impact on the dual chartering of banks.

After a long period of comparative equilibrium, there was again in the middle I950s a slight rise in the percentage of state banks, and this trend continued until the early 1960 s. In I 960 national banks constituted 33.8 per cent of all banks, yet by I964 national banks represented 34.7 per cent of the total. These figures reflect a net increase of 193 national banks over the four years, in contrast to a corresponding increase of 135 state banks over the same period. The early I96os also marked the first period in almost forty years in which the absolute number of national banks had shown an increase. Some of the factors contributing to this reversal of trend are discussed below.

Figures on the number of banks do not, of course, tell a complete story, for they do not show the size of banks in each category. Statistics on bank size also demonstrate the durability of the dual banking system and, more important, reflect more dramatically the recent trend to national bank status. As of December 3r, I965, national banks constituted approximately thirty-four per cent of the total number of banks, yet held fifty-one per cent of all bank assets. ${ }^{21}$ This represented an increase from 45.6 per cent in 1962 in the proportionate share of assets held by national banks.2 The greater proportionate increase in the assets controlled by national banks over the number of banks in the national-bank category is explained, of course, by the large size of the banks that converted from state to national status. The Chase Manhattan Bank of New York was the largest state-chartered bank in the country

\footnotetext{
21 1965 FDIC ANN. REP. 99.

${ }^{22}$ Based on data given in 1962 FDIC ANN. REP. 46.
} 
when it converted in 1965 . This important development is reviewed below as a means of identifying some aspects of the new impetus for a switch to national charters.

\section{B. The Relative Competitive Positions of National and State Banks}

It has often been stated that one effect of the dual banking system has been to create "competition in laxity" between national and state governments. ${ }^{23}$ It is undoubtedly true that applicants for charters have been sensitive to differences in requirements on capitalization, size of reserves, loan privileges, and other matters. They have been sensitive, also, to differences in the rigor of bank examinations and reporting requirements. There have been factors that gave a competitive advantage to the state in the options offered to those entering the banking business. Lower capitalization and reserve requirements and more liberal loan policies have often made state chartering more attractive than national chartering. National banks were not allowed to make real estate loans until I9I6, to act in fiduciary capacities until rgr3, and to engage in branch banking until r927. The assumption of authority by the Comptroller of the Currency in rgog to consider community needs for banking in the granting of charters led to a more restrictive policy than existed in many states whose policies leaned toward "free banking."24 The Federal Reserve Board's institution of compulsory par clearance in I9r6, which was vigorously opposed by many banks within the Federal Reserve System, made state banking without Reserve membership still more attractive to many banks. ${ }^{25}$ Compulsory membership in the Federal Reserve System for national banks is itself a deterrent to choice of national bank status by some banking institutions. Reserve membership entails subjection to many restrictions not applicable to nonmembers.

There have been liberalizations of national bank restrictions that had the effect of making the national system more competitive. Notable was the lowering in rgoo of minimum capital requirements from $\$ 50,000$ to $\$ 25,000$. The lower level remained in effect until I933. In Ig06 national banks were authorized to lend to one person or firm ten per cent of its capital and surplus instead of ten per cent of its capital alone. Among other instances of liberalization have been the authority to lend on real estate, to engage in fiduciary relationships, to accept time deposits, to establish branches in states granting the privilege, and to act as broker or agent in small cities in placing loans on real estate.

The competitive advantages of the state systems, and the "competition in laxity," have sometimes been of deep concern to some authorities on banking. This concern was repeatedly expressed in the I920s, especially after the rise in number of bank failures during the Depression. The Comptroller commented at length in Ig22 on

\footnotetext{
${ }^{23}$ See, e.g., authority cited note 35 infra.

24 See igog Comptroller of the Currency ANN. Rep. I8; I9Io Comptroller of the Currency ANN. Rep. I8-Ig.

${ }^{26}$ For a story of the par remittance controversy, see ANDERson, supra note II, at 89-142.
} 
the threat to national bank status in the option for membership in the Federal Reserve System offered to state banks. ${ }^{26}$ In $x 926$ he reported that from October $3{ }^{\mathrm{I}}$, 1923 to October I7, I925, I66 national banks with assets of $\$ 566,600,000$ converted to state banks, and that from October $\mathrm{I} 7$, 1925 to October I, 1926, another eighty-seven with assets of about $\$ 560$ million converted. During the latter period, in contrast, twentynine state banks with assets of about $\$ 235$ million converted to national banks. ${ }^{27}$ Professor H. Parker Willis of Columbia University submitted to Congress in I926 a lengthy and thorough analysis of deficiencies in state bank supervision. ${ }^{28}$ Admission of national banks to the privileges of state banks in branch banking was presented as a remedy by persons testifying in $x 926$ on the McFadden bill. ${ }^{29}$ But the greatest concern came after the rash of bank failures in the Depression. Figures have been assembled that show a superior record on bank failure for banks under national supervision from I92I to I932. The average annual rate of suspensions during that period was 4.08 per cent of the average number of nonmember banks, but only r.88 per cent for member banks and 1.79 per cent for national banks. ${ }^{30}$ The failure between $I 930$ and I932 of 5,096 banks, of which 4,062 were nonmember banks, ${ }^{31}$ made banking policy the foremost issue for the nation. There were some who held the view succinctly expressed by Senator Carter Glass, a national banking authority: "The dual system of banking has seemed to me to be an almost insuperable obstacle in the way of sound banking legislation." ${ }^{.32}$

Yet the reforms of 1933 and 1935 found solutions to the immediate problems without any attack on dual chartering. The requirements on national banks alone and on member banks were tightened. Deposit insurance provided a means of national supervision without requiring national charters. By providing new security for all banks it safeguarded dual chartering. In effect, insurance of deposits of minimum size under national supervision also insured the dual banking system. From 1935 to $x 96 x$ the competitive positions of national and state banking remained relatively stable, and security has yielded to other banking issues. Recently, there has been a movement toward liberalization of banking privileges, with the national government taking the initiative. From Ig6I to Ig66 Comptroller Saxon liberalized the rules for national banks in numerous ways. Back of this development was the recognition of the strong competitition for commercial banks from other types of financial institutions and the belief that loan privileges could be extended without serious decline in the quality of loans. Because of liberalization at the national

\footnotetext{
${ }^{26}$ I922 Comptroller of the CURRency ANn. Rep. 2-3.

27 I926 COMPTROLLER OF THE CURRENCY ANN. REP. 2.

${ }^{28}$ Hearings on S. 1782 and H.R. 2 Before a Subcomm. of the Senate Comm. on Banking and Currency, 69th Cong., Ist Sess. 46-16o (1926).

${ }^{28} \mathrm{Id}$. at $16 \mathrm{ff}$.

${ }^{30}$ ANDERson, supra note $\mathrm{II}$, at $3 \mathrm{I2}$.

${ }^{81}$ Id.

${ }^{32}$ Hearings Purstant to S. Res. $7_{1}$ Before a Stubcomm. of the Senate Comm. on Banking and Currency, 7Ist Cong., 3d Sess., pt. I, at 265 (r93I).
} 
level, state banking authorities have had to re-examine their rules. For example, reports by a prestigious advisory committee in New York in December 1965 and September 1966 assessed the competitive inequalities between New York state banks and national banks, and made many recommendations for liberalization of state requirements. ${ }^{33}$ It is inevitable that liberalization at the national level will have an influence on state regulations, ${ }^{34}$ in the same way that liberal rules in state jurisdictions had an effect in earlier periods on the national rules. ${ }^{35}$

\section{Illustrations of the Recent Trend to National Bank Status}

The most startling manifestation of the new trend toward national bank status was the conversion of New York's Chase Manhattan Bank to a national charter in I965. At that time it was the largest state-chartered bank and the third largest commercial bank in the United States. Other large banks, including the (now) Provident National Bank in Philadelphia and the Mercantile Trust Company of St. Louis, have made the switch in recent years.

Shortly after the Chase decided to renounce its r66-year-old state charter, an article discussing the implications of the conversion appeared in the New York Times. ${ }^{36}$ In an interview with the Times reporter, one of Chase's senior officials summed up the chief advantages of being a national bank in one word-"flexibility." More specifically, the officer was reported as citing the following as among its reasons for the change: (I) "some states, such as Pennsylvania and Illinois, summarily prohibit state chartered banks of other states from doing business in their territory"; (2) "certificates of deposit of national banks ... [are] not subject to "blue sky laws'"; and (3) "state banks 'still can't sell [travelers checks] in Illinois and Pennsylvania." "

The president of the Provident National Bank was reported as pointing out that "stockholders of state chartered banks living in states other than those in which the bank operates paid taxes on dividends, which was not the case with stockholders of national banks." And both he and the president of Mercantile Trust added that "the swiftness with which Mr. Saxon acted on branching applications was a factor." In this connection, the reporter suggested that "in New York, as in some other states, consideration must also be given to the effect on state chartered mutual savings banks, an obstacle Mr. Saxon does not face." Other factors which the Times discussion

\footnotetext{
${ }^{33}$ Advisory Commitiee on Commercial Bank Supervision, Report Submitted to the SuperinTENDENT of Banks of State of New YoRk (December 1965) [hereinafter cited as New YoRk Advisory Committee, First Report]; Advisory Committee on Commercial Bank Supervision, Second Report Submitted to the Superintendent of Banks of the State of New York (September x966).

"See Wille, State Banking: A Study in Dual Regulation, in this symposium, p. 733.

${ }^{85}$ For a view that there is still a dangerous tendency toward a "race of laxity," see the statement of J. L. Robertson, Member of the Board of Governors of the Federal Reserve System, in Hearings on Proposed Federal Banking Commission and Federal Deposit and Savings Insurance Board Before the Subcomm. on Bank Supervision and Instrance of the House Comm. on Banking and Currency, 88th Cong., Ist Sess. 174, 177 (1963). See also Robertson, Federal Regulation of Banking: $A$ Plea for Unification, in this symposium, p. 673 .

${ }^{80}$ Frost, Chase Bank Move Has Broad Impact, N.Y. Times, July $x 8$, 1965, $\$ 3$, at I, col. 8 .
} 
mentioned as favoring national bank status were that: (I) "state chartered banks operating in other states are taxed as 'out-of-state corporations,' while national banks are immune from such taxes"; (2) "the New York lawmakers have . . . failed to give its state chartered banks the right to go into direct equipment leasing and the factoring business"; and (3) "national banks have been given broader powers in the underwriting of certain tax-exempt issues."

Several striking features of the new intersystem competition are evident. First, the competitive handicaps cited by the Chase were not strictly those attributable to New York law, which at the time was relatively up to date if not in advance of the field in modernization; the defensive laws of other states, preventing or inhibiting various kinds of interstate business except under a national charter, were perhaps the primary factor cited. In addition, the motivating factors in recent years are apt also to include regulatory differences originating at the national level in conflicts between the Comptroller and the other two banking agencies in Washington. ${ }^{37}$ The result of these circumstances is that no state legislature can rectify the situation acting alone, either because the problem results from the laws of other states or because it reflects the multiplicity of regulatory systems at the national level. Thus, the banking business and bank regulation have apparently become so complex and pervasive that state systems no longer fully control their own destiny through the power to legislate inducements. We will have occasion below to see how the states are being encircled and regulatory power drained to Washington.

\section{III}

\section{BANK SUPERVISION}

While grant or denial of charters is the initial means of enforcing the requirements of national and state banking laws, continuous enforcement of these policies is sought by examination and by requirement of reports. All bank supervisory agencies depend on these two techniques of supervision. Regular, and sometimes special, reports are required. Examinations are conducted on regular schedules and are supplemented on occasions by additional examinations of particular banks deemed to be in need of more than normal supervision.

Exercise of these functions is divided in the national government. The Federal Reserve officials call for one regular report a year from banks subject to their jurisdiction, and may require a second one. The FDIC calls for reports on a selective basis. The Comptroller calls for regular and sometimes for special reports. All three agencies are interested in bank examinations, but the Comptroller in practice conducts all bank examinations for solvent national banks. Every state has a banking board or commission, or a banking commissioner, or a combination of the two, with titles varying among the states. These require reports and conduct examinations.

\footnotetext{
${ }^{37}$ See generally Robertson, Federal Regulation of Banking: A Plea for Unification, in this symposium, p. 673; Wille, supra note 34 .
} 
In addition, state member banks are examined by the Federal Reserve Board and nonmember insured banks by the FDIC.

Although facts for comparison of the quality of bank examinations in national and state jurisdictions are not at hand, some factors that may affect quality can be noted. As of August 26, I966, the Comptroller had I,I30 regular bank examiners and ninety-seven specialized examiners for trust departments of banks. There is approximately one regular bank examiner for every four national banks. New examiners with bachelor's degrees are recruited as trainees with annual salaries, in August Ig66, of $\$ 6,46 \mathrm{I}$. A fully trained bank examiner with full responsibility as an examiner had a minimum grade of GS-II and a minimum salary of \$9,22I. Bank examiners and supervisors on the job had salaries ranging from $\$ 7,550$ to $\$ 23,013$. The average grade level was GS-9 and the average tenure was about twelve years. The Comptroller's term is only five years, and most Comptrollers have not finished their terms, due primarily to lucrative offers of other employment; ${ }^{38}$ nevertheless, the traditions and practices of the long-established agency with respect to bank examinations have produced continuity and great stability in standards.

A questionnaire to the state banking authorities on banking personnel brought a reply from forty-three states. The replies to questions, insofar as these were given, are tabulated in Table 2. Only in New York do salary levels of examiners appear to be fully comparable to those in the national service. In a few others (California, Iowa) the top salary reaches $\$ 15,000$ per annum. Average salaries in the states were not obtained, but the lower and upper limits indicate distinctly lower salaries in many states than in the national service. Average tenure reported for examiners ranged from two and a half years in Nebraska, three and a half in Montana, four in Wyoming, and four and a half in Vermont to fifteen in Arkansas and twenty in Tennessee. Average tenure of commissioners in states having a board or commission ranged from three in Kansas, Ohio, and South Dakota to ten in Montana, with many states not reporting; of commissioners in states with a single bank commissioner from one and a half in Minnesota and two in Nebraska to sixteen in Tennessee and nearly fifteen in Delaware, again with many states not reporting. Figures on average number of banks per examiner varied greatly and are apparently without significance because of variations in size of banks and number of branches within the several states. It is apparent that these figures offer little basis for firm conclusions. It does appear that in many states salaries for bank examiners are low in comparison with those in the national system and that tenure of bank examiners is also relatively low in some state systems.

Despite differences in requirements in the several jurisdictions and in the provisions for supervision, there has been a tendency toward uniformity in standards. Chairman Martin of the Federal Reserve Board reported to a House subcommittee in

\footnotetext{
${ }^{38}$ For a summary of Comptrollers' backgrounds, tenure, and resignations, see Fox, supra note 4 , at I $0-16$.
} 
TABLE 2

Data Concerning State Bank Supervisory Agencies

\begin{tabular}{|c|c|c|c|c|c|c|c|c|}
\hline \multirow[b]{3}{*}{ State } & \multirow[b]{3}{*}{ 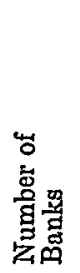 } & \multirow[b]{3}{*}{ 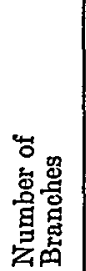 } & \multicolumn{4}{|c|}{ Examiners } & \multirow{3}{*}{ 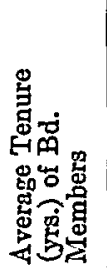 } & \multirow{3}{*}{ 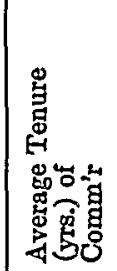 } \\
\hline & & & \multirow[b]{2}{*}{$\begin{array}{l}\text { 岕 } \\
\text { 兽 } \\
\end{array}$} & \multicolumn{2}{|c|}{ Salary } & \multirow{2}{*}{ 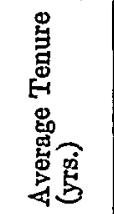 } & & \\
\hline & & & & From & To & & & \\
\hline Alaska.. & 9 & 7 & \multicolumn{3}{|c|}{1 part-time $>\$ 50$ per day $<$} & - & - & - \\
\hline Arizons. & 12 & 72 & 7 & $\$ 6,000$ & $\$ 8,400$ & $51 / 6$ & - & 4 \\
\hline Arkansas. & 182 & 41 & 15 & $\$ 6,000$ & $\$ 9,000$ & 15 & 5 & $1 \hat{2}$ \\
\hline California. & 98 & 666 & 59 & $\$ 8,532$ & $\$ 15,300$ & - & & $31 / 3$ \\
\hline Delaware.. & 17 & 72 & 6 & $\$ 5,000$ & $\$ 8,500$ & 6510 & - & $1411 / 12$ \\
\hline Florida... & 334 & $\overline{73}$ & $\begin{array}{l}32 \\
22\end{array}$ & $\begin{array}{l}\$ 4,200 \\
\$ 6,372\end{array}$ & $\begin{array}{l}\$ 10,560 \\
\$ 13,908\end{array}$ & $\begin{array}{ll}6 & 5 / 6 \\
6 & 1 / 2\end{array}$ & $=$ & 二 \\
\hline $\begin{array}{l}\text { Heorgail. } \\
\text { Hawai. }\end{array}$ & $\begin{array}{r}00 x \\
5\end{array}$ & 81 & 14 & $\$ 6,300$ & $\$ 11,940$ & $1 / 2$ & 二 & 二 \\
\hline Indiana.. & 303 & 203 & 17 & $\$ 5,760$ & $\$ 12,840$ & & 4 & 一 \\
\hline Iowa...... & 567 & - & 43 & $\$ 6,000$ & $\$ 15,000$ & $71 / 2$ & 4 & 4 \\
\hline Kentucky. & 267 & 107 & 16 & $\$ 5,484$ & $\$ 9,852$ & -2 & & 4 \\
\hline Kan & 430 & -1 & 20 & $\$ 6,062$ & $\$ 11,940$ & & 3 & 4 \\
\hline Iouisiana. & 172 & 136 & 18 & $\$ 7,200$ & $\$ 11,160$ & & & 4 to 8 \\
\hline Maine... & 59 & 121 & 12 & $\$ 5,148$ & $\$ 10,712$ & $91 / 2$ & - & $45 / 12$ \\
\hline Minnesota. & 530 & -1 & 48 & $\$ 5,616$ & $\$ 11,856$ & - & - & $11 / 2$ \\
\hline Mississippi & 155 & - & 23 & & $\$ 10,000$ & 7 & - & - \\
\hline Missouri & 573 & - & 55 & $\$ 6,500$ & $\$ 10,000$ & 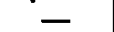 & 一 & - \\
\hline Montana.. & 84 & - & 8 & $\$ 6,000$ & $\$ 9,600$ & $31 / 2$ & 10 & $=$ \\
\hline Nebraska. & 307 & - & 20 & $\$ 5,100$ & $\$ 10,000$ & $21 / 2$ & - & 2 \\
\hline Nevada.. & 6 & 31 & 7 & $\$ 7,080$ & 58,760 & - & - & 6 \\
\hline New Ham & 17 & 02 & 15 & $\$ 6,200$ & $\$ 11,830$ & 10 & ( & 9 \\
\hline $\mathrm{Ne}$ & - & 264 & 43 & $\$ 6,063$ & $\$ 14,151$ & - & - & - \\
\hline New Mexico & 30 & 48 & 6 & $\$ 5,040$ & $\$ 9,620$ & & - & - \\
\hline New York..... & 133 & 1,069 & 301 & $\$ 8,365$ & 323,900 & $101 / 2$ & - & - \\
\hline North Carolina. & 114 & 492 & 22 & $\$ 6,036$ & $\$ 11,808$ & & 4 & - \\
\hline & 319 & 431 & 33 & $\$ 5,520$ & $\$ 9,000$ & - & 3 & - \\
\hline Oblaho & 201 & -1 & 16 & $\$ 6,600$ & $\$ 8,700$ & 10 & 0 & - \\
\hline Oregon.. & 40 & 55 & 6 & $\$ 6,300$ & $\$ 10,140$ & $41 / 2$ & - & $52 / 3$ \\
\hline lvan & 204 & 526 & 61 & $\$ 6,090$ & $\$ 11,501$ & $151 / 2$ & - & 4 \\
\hline South Caro & 103 & 100 & 13 & $\$ 5,775$ & $\$ 10,707$ & 一 & - & \\
\hline South Dako & 135 & 41 & 8 & $\$ 5,400$ & $\$ 9,000$ & - & 3 & $31 / 4$ \\
\hline Tennessee. & 221 & 222 & 18 & $\$ 6,000$ & $\$ 10,800$ & 20 & 0 & $16^{1 / x}$ \\
\hline Texas. & 593 & - & 23 & $\$ 7,500$ & $\$ 14,400$ & - & - & 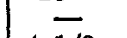 \\
\hline Utah. & 43 & 52 & 12 & $\$ 5,388$ & $\$ 12,732$ & - & - & $41 / 3$ \\
\hline Vermo & 27 & 26 & 6 & $\$ 5,174$ & S8,372 & $41 / 2$ & - & $31 / 2$ \\
\hline Virgini & 141 & 213 & 24 & $\$ 5,640$ & $\$ 10,992$ & - & 一 & 7 \\
\hline West Virginia & 109 & - & 11 & $\$ 4,800$ & $\$ 9,600$ & - & - & 5 \\
\hline Wisec & 480 & 134 & 35 & $\$ 7,000$ & $\$ 16,000$ & - & 5 & 6 \\
\hline Wyoming. & 29 & $20 x$ & 5 & $\$ 5,700$ & $\$ 8,460$ & 4 & 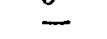 & 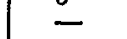 \\
\hline
\end{tabular}

So:trce: Author's questionaire to bank supervisory authority in each state. Other states did not respond.

I963 that over the years there had been a considerable amount of cooperation among the national agencies and with the state supervisors of banking, especially in developing and maintaining desirable and uniform standards of supervision. ${ }^{30}$ Such standardization was inevitable after the offer of deposit insurance to state banks.

\footnotetext{
${ }^{30}$ Statement by William McChesney Martin, Jr., Chairman, Board of Governors of the Federal Reserve System, in Hearings, supra note 35 , at 168.
} 
Agreements on bank examinations and reporting procedure were worked out by the three national agencies and the Executive Committee of the National Association of Supervisors of State Banks in 1938 and renewed in r949. Today, there is cooperation through concurrent examinations, alternate examinations by national and state examiners, and exchange of reports between national and state authorities. Although some states reported on a questionnaire that no concurrent or alternate examinations were arranged, most states reported the opposite. New York, for example, reported as follows:

State-chartered commercial banks which are members of the Federal Reserve System are examined concurrently by State and Federal Reserve examiners. A separate report is issued by each agency. Insured, non-member commercial banks and savings banks chartered by the State are usually examined concurrently by state examiners and Federal Deposit Insurance examiners.

Pennsylvania reported rather precisely:

About 75 percent of all examinations are conducted on joint, cooperative basis with Federal Reserve and FDIC. The other 25 percent alternate since state examiners on occasion are all needed to conduct joint examination of large member or nonmember banks, and on these occasions, the other federal supervisory agency will conduct independent examinations.

A number of states reported the general practice of a concurrent examination on one examination a year, but with variations in the practice where schedules of state examiners and those of FDIC examiners, particularly for small bank examinations, could not be coordinated. Bank supervision presents, therefore, another example of cooperative federalism. ${ }^{40}$

IV

\section{National Deference to State Policy}

In numerous statutory provisions the national government accepts the policy of the several states, for their respective jurisdictions, as controlling for national bank operations and national policy on banking. This deference to the states extends from the simple comity that one jurisdiction accords another to what appears to be outright delegation of major policy decisions by Congress to the separate states. In general the overriding national policy has been one of promoting "competitive equality" between national and state banks as the most feasible means of preserving dual banking. ${ }^{41}$ Competitive equality might also have been achieved by legislation extending national regulation to state banks to whatever degree was necessary to protect the national banking system; $;^{42}$ Congress's decision to give wider scope to

\footnotetext{
${ }^{10}$ See Wille, supra note 34 , at 735-38.

"I First Nat'l Bank of Logan v. Walker Bank \& Trust Co., 385 U.S. 252 (1966) (involving competitive equality in the field of branch banking), discussed in text accompanying notes 6I-63 infra.

${ }^{22}$ Cf. Houston, E. \& W. T. Tex. Ry. v. United States, 234 U.S. 342 (19I4) (the Shreveport case). It may be significant that Congress chose rather not to diminish the role of the states in bank regulation.
} 
local law thus represents not so much a delegation of national power as a refusal to exercise that power to its fullest extent. ${ }^{43}$

\section{A. Trust Operations and Miscellaneous Actions}

The policy of the Congress on allowing trust operations by national banks is to give them a position comparable to, but no more favorable than, that of state banks. To accomplish this the policies of the states with respect to state banks are accepted for national banks. The national statute authorizes the Comptroller to grant by special permit to national banks, on their application, those particular trust powers allowed to state banks, trust companies, or other corporations which come into competition with national banks. ${ }^{44}$ A rule of comity allows state banking authorities access to reports of examination by the Comptroller insofar as these relate to trust operations but does not allow state access to the records of the banks. ${ }^{45}$ Another statutory provision requires national banks acting in a fiduciary capacity to deposit securities with state authorities for protection of private or court trusts when state law requires this of corporations; national banks can execute bonds in such cases if state law requires it for other corporations. ${ }^{46}$ State policy is also adopted in a provision that prohibits grant of a permit to a national bank for fiduciary powers unless it has capital and surplus equal to that required by state law for state banks, trust companies, or other corporations exercising fiduciary powers. ${ }^{47}$ Also, a national bank desiring to terminate trust powers must show to the Comptroller that it has been relieved of all requirements of state law on its trust operations. ${ }^{48}$ Regulation Nine of the Comptroller on "Fiduciary Powers of National Banks and Collective Investment Funds" makes numerous types of action by national banks contingent upon authorization of, or not being in contravention of, local law (i.e., "the law of the State or other jurisdiction governing the fiduciary relationship")..$^{49}$

Similar deference to state law is shown in other provisions of the banking laws. Thus, the rate of interest allowed for a national banking association is that allowed

\footnotetext{
${ }^{13}$ It does not seem necessary to debate whether we have here cases of delegation of legislative power in the usual sense. See, e.g., L. L. Jaffe, Judicial Control of Administrative Action ch. 2 (r965); K. C. Davis, Administrative Law Treatise ch. 2 (1958). However, it does seem that Congress adopted the chosen approach not as a means of turning the regulatory problems over to agents more capable of handling the difficult economic issues, or even of weighing supposed "local interests," but mercly as an expedient means of maintaining the desired competitive equality. Also notable is the difficulty the state may encounter in effectively enforcing state policy under the present scheme. See Comment, Banks and Banking: Authority of State Banking Superintendent to Challenge Branching Activities of National Banks, 1967 Duke L.J. 72, discussing the ability of state banking officials to bring suit under state law (a pre-emption problem) or under federal law (a standing problem) to enforce state branching policies against national banks where the Comptroller of the Currency has improperly applied statc law. The student author has posed nicely some of the delicate federalism problems created by recent efforts of the Comptroller to subvert restrictive state policies in the interest of freer banking.

1 I2 U.S.C. $\$ 92 a(a)(1964)$.

15 I2 U.S.C. $\$ 92 a(c)(1964)$.

40 I2 U.S.C. $\$ 92 a(f)(1964)$.

17 I2 U.S.C. $\$ 92 \mathrm{a}(\mathrm{i})(1964)$.

48 I2 U.S.C. $\$ 92 \mathrm{a}(\mathrm{j})\left(\mathrm{Ig6}_{4}\right)$.

${ }^{10} 12$ C.F.R. $\$ 9 . I(f)$ (Supp. I966).
} 
by the state for its state banks, if a rate is fixed by the state. ${ }^{50}$ Thus, also, a national bank shall not be organized in a city of more than 50,000 population with capital of less than $\$ 100,000$, except in outlying districts where state law allows organization with a smaller capitalization. ${ }^{51}$ Again, a state bank may be converted into a national bank, provided such conversion "shall not be in contravention of the State law."

\section{B. Branch Banking}

The most significant national deference to the states is on branch banking. On this-as on trust powers-the national government adopts the policies of the states, once again apparently in order to insure equality between national and state banks. National policy-or lack of policy-on branch banking is, therefore, a substantial support for the existing system of dual banking.

An amendment to the National Banking Act in I865 allowed a state bank with branches to become a national banking association and retain its branches. ${ }^{53}$ No other authority for branch banking by national banks appeared in the statutes until $1927,{ }^{54}$ at which time the need was felt to protect national banks against branching by state bank competitors in states where branching was permitted. The McFadden Act in $1927,{ }^{55}$ and subsequent amendments of $1933^{56}$ and $1962,{ }^{57}$ generally authorized branch banking by national banks on conditions equivalent to those for state banks. The requirement for conformity with state law, contained in section $36(c)$ of the National Banking Act, is seemingly a tight one: a national bank may be authorized by the Comptroller to establish and operate branches (I) within its city, town, or village "if such establishment and operation are at the time expressly authorized to State banks by the law of the State in question," "if such establishment and operation are at the time authorized to State banks by the statute law of the State in question by language specifically granting such authority affirmatively and not merely by implication or recognition, and subject to the restrictions as to location imposed by the law of the State on State banks."59

In addition, the national bank establishing branches outside its city must have the minimum capital stock, or capital stock and surplus combined, required by state law for a state bank establishing branches. ${ }^{60}$

\footnotetext{
${ }^{00}$ I2 U.S.C. $\$ 85(1964)$.

81 I2 U.S.C. $\S 5 \mathrm{I}(\mathrm{Ig} 64)$.

${ }^{82}$ I2 U.S.C. $\$ 35$ (1964).

${ }^{63}$ Act of March $3,1865, \mathrm{ch} .78, \S 7,13$ Stat. 484 .

"Es First Nat'l Bank in St. Louis v. Missouri, 263 U.S. 640 (I924).

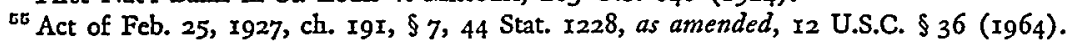

${ }^{50}$ Act of June $I 6$, I933, ch. $89, \$ 23,48$ Stat. I89.

${ }^{67}$ Act of Sept. 28 , r962, Pub. L. No. $87-72 r, 76$ Stat. 667.

${ }^{18}$ I2 U.S.C. $\$ 36(c)(\mathrm{I})(\mathrm{Ig} 64)$.

${ }^{10}$ I2 U.S.C. $\$ 36(\mathrm{c})(2)$ (1964). The phrase "statute law" includes the legislative enactments only and not administrative interpretations of those enactments. Union Sav. Bank of Patchogue v. Saxon, 335 F.2d 7r8 (D.C. Cir. 1964 ).

${ }^{60}$ I2 U.S.C. $\$ 36$ (c) $(1964)$. An exception to the requirements is made for certain seasonal branch operations for areas where no bank is located.
} 
The Supreme Court has only recently ruled on the precise application of the first clause, namely the limitation on branches within the city, town, or village within which the branching bank is located. The case, First National Bank of Logan $v$. Walker Bank \& Trust Co., ${ }^{61}$ involved the contention of the Comptroller of the Currency and the branching national bank that a national bank could branch in its home community if a state bank could under any conditions maintain a branch there notwithstanding that the national bank did not meet the conditions specified in the state statute. ${ }^{62}$ In rejecting the Comptroller's argument, the Court relied heavily on legislative history and reaffirmed the statutory policy of "competitive equality." ${ }^{33}$ The Court also dealt in dictum with the second clause of section $36(c)$ governing "outside" branching, concluding that the principle of competitive equality was again intended to operate.

The law on branching has thus been an important battleground in the federal-state conflict over banking policy. ${ }^{63 a}$ The Walker Bank \& Trust Co. case appears to have put to an end the Comptroller's effort to circumvent state branching restrictions in the interest of freer banking, a goal that many deem desirable but that state legislatures have been slow to adopt. ${ }^{64}$ One continues to expect the future of dual banking to be determined in large measure in the branching struggle. By this decision, however, the Supreme Court may have removed the branching controversy from judicial and administrative forums to the political arena. ${ }^{05}$

\section{The Bank Holding Company Act}

The Bank Holding Company Act of $195^{68}$ contains a number of provisions

\footnotetext{
${ }^{61} 385$ U.S. 252 (1966).

${ }^{02}$ Id. at $26 \mathrm{I}$.

${ }^{63}$ On the subject of hometown branching, the Court said the following:

"The bill originated in the House and, in substance, proposed that both national and state banks be permitted to establish 'inside' branches within the municipality of their main banking facilities in those States that permitted branch banking at the time of the enactment of the bill. H.R. Rcp. No. 83,69 th Cong., Ist Sess. 4-5 (I926). The intent of the Congress to leave the question of the desirability of branch banking up to the States is indicated by the fact that the Senate struck from the House bill the time limitation, thus permitting a subsequent change in state law to have a corresponding effect on the authority of national banks to engage in branching. The Senate Report concluded that the Act should permit 'national banks to have branches in those citics where State banks are allowed to have them under State laws.' S. Rep. No. 473, 69th Cong., 1st Sess., 14 (1926). In the subsequent Conference Committee, the Senate position was adopted."

Id. at 258 .

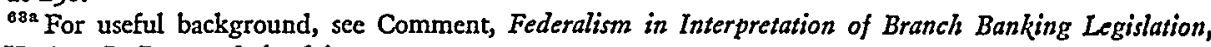
32 U. CHI. L. REv. I48 (1964).

${ }^{64}$ Former Comptroller James J. Saxon attempted during his tenure from I96r to I966 an overt attack on what he regarded as antiquated state banking laws. See Bratter, Fresh Air in the Comptroller's Office, Banking, July 1962, at 45, I30, quoting Saxon as follows: "Admittedly we are putting on the pressure all over the country. It is no accident; it is deliberate and calculated. We hope that the states will pick up the ball ...." See also text accompanying notes 93-roo infra.

${ }^{65}$ About the only open question would appear to be the ability of state banking officials to enforce state policies against national banks. See Comment, Banks and Banking: Authority of State Banking Superintendent to Challenge Branching Activities of National Banks, 1967 Duke L.J. 72, discussed note 43 supra.

${ }^{00}$ I2 U.S.C.A. $\$ \$$ I84I-49 (Supp. 1966). See generally Note, Federal-State Relations Under the Bank Holding Company Act of 1956, 66 YALE L.J. I093 (1957).
} 
calculated to preserve the position of the states in bank regulation. A rule of comity requires the Board of Governors, upon receiving an application for approval of an acquisition under the act, to notify the "supervisory authority of the interested State, if the applicant company or any bank the voting shares or assets of which are sought to be acquired is a State bank." application then the Board must hold a hearing before granting or denying the application. $^{68}$ Another provision of the act (the so-called Douglas Amendment) adopts the policy of the state on out-of-state acquisitions of additional banks within the state, whether affected through purchase of stock or of "substantially all of the assets." Such acquisitions must be "specifically authorized by the statute laws of the State in which such bank is located, by language to that effect and not merely by implication."70 Finally, in a sweeping abdication of authority to the states the act provides, "The enactment by the Congress of this chapter shall not be construed as preventing any State from exercising such powers and jurisdiction which it now has or may hereafter have with respect to banks, bank holding companies, and subsidiaries thereof." ${ }^{\prime 71}$ In upholding an Illinois statute the state's supreme court said with respect to this provision:

The Illinois legislation, as well as legislation in New York, New Jersey, Pennsylvania and Indiana, is an acceptance of the suggestion implied in the Federal act that the States should act if, as a matter of policy, bank holding company legislation more restrictive than the Federal act, was desired by the States. Further, it seems clear that such State legislation could be applicable to national as well as State banks, since the Congress did not manifest an intent to pre-empt the legislative field. ${ }^{2}$

Similarly, a judicial advisory opinion has been given by another state court that a state multiple banking law applicable to national banks doing business within a state would not be invalid "unless it were found to interfere with the purposes of the national banks or to destroy their efficiency or to be in direct conflict with some paramount federal law." 73 These views seem fully consistent with the overriding congressional policy of preserving the competitive equilibrium between national and state banks.

\section{ENCIRCLEMENT OF THE StaTeS}

Although the preceding sections show that the position of the state has been

${ }^{\mathrm{ar}} \mathrm{I2}_{2}$ U.S.C. $\$ 18_{42}$ (b) (1964).

${ }^{08} \mathrm{Id}$.

${ }^{00}$ I2 U.S.C.A. $\$ 1842$ (d) (Supp. I966).

${ }^{70} \mathrm{Id}$.

${ }^{71}$ I2 U.S.C. $\$ 1846$ (Ig64).

${ }^{72}$ Braeburn Securities Corp. v. Smith, 55 Ill. 2d 55, 6r-62, 153 N.E.2d 806, 8 ro (1958), appeal dismissed for want of a substantial federal question, 359 U.S. 3 II (1959).

${ }^{78}$ Opinion of the Justices, I5I A.2d 236, 239, 102 N.H. 106, 109 (1959). 
preserved in banking regulation, it is also true that there have been some developments in the opposite direciton. Federalism is, in the case of banking regulation, a Janus, with one face looking toward adoption of state policy while the other looks toward encirclement of the state banking systems by uniform national policy. On account of the peculiar historical development of the dual banking system the encirclement is limited. Moreover, it is not purposeful; it is an incidental effect of national policies. It has, nevertheless, some significant dimensions.

It has already been noted that eclipse of the state banking system was part of Chase's plan. The taxation of state-bank notes removed the state banks from the currency issue function. This in itself was a considerable encirclement of the state banking system, but was not fatal to it because of the rise of deposit banking.

No further step toward encirclement occurred until the Federal Reserve System was established. The advantages of membership have led most of the large state banks to choose to be members. Today approximately forty-five per cent of the banks (all of the approximately 4,500 national banks and about 1,500 state banks) of the nation, holding eighty-four per cent of commercial-bank deposits, are members of the System. This brings five-sixths of deposit banking under the rules and jurisdiction of the Federal Reserve.

The state member banks are allowed to retain charter rights as state banks, but they have become subject additionally to the Federal Reserve's authority in the same way that national banks are. They are examined annually by the System, and each must make reports to the Federal Reserve Bank of which it is a member. A state bank can be expelled from membership, its officers and directors removed for continued violation of law or unsound banking practices, and its discount privileges reduced or suspended. It is subject to additional substantive regulation. As a condition of membership it may have to give up some of its charter rights. Of major importance are larger reserve requirements and more rigid loan restrictions than may exist under the state jurisdiction to which they are subject. They must clear checks forwarded to them at par. They are subject to miscellaneous other requirements with respect to such matters as underwriting operations of its personnel, granting of acceptance credit, acceptance of drafts above fifty per cent of their capital and surplus, maintenance of capital stock and surplus deemed by the Board of Governors to be adequate, and rate of interest on time and savings deposits. Also, the law provides that all member banks, during an emergency declared by the President, shall transact business under such regulations as may be issued by the Secretary of the Treasury with the approval of the President. ${ }^{74}$

The Federal Deposit Insurance Act also brought state banks under national jurisdiction-albeit, again, through their choice. Nonmember insured banks are subject to national rule making, e.g., the authority of FDIC to set their rates of interest

${ }^{74}$ I2 U.S.C. $\$ 95$ (1964). 
on time and savings deposits. They are subject to examination and reporting requirements of the FDIC. About ninety-eight per cent of the commercial banks of the nation, with about ninety-nine per cent of the deposits, are insured under the act. While insurance of state bank deposits up to $\$ 15,000$ has helped insure the survival of dual banking, ${ }^{75}$ it has done so by subjecting virtually all banks to a single jurisdiction on requirements for bank safety. ${ }^{78}$

In the case of the Federal Reserve and the FDIC, the benefits offered to state banks lead to the acceptance of national jurisdiction. In some other cases national policy is compulsory. The bank-closing order of the President in I933 applied to all banks. The Securities Exchange Act of 1934 gave the Federal Reserve Board authority to prescribe regulations on the amount of credit for stock purchases that are applicable to all banks. ${ }^{77}$ Although states are allowed to adopt stricter standards on bank holding companies, the Bank Holding Company Act of 1956 establishes unified national supervision of all bank holding companies and national approval of holding company acquisitions. ${ }^{78}$ The bank merger legislation of $I 960$ and $I 966$ applies to all insured banks and places responsibility for administration in the three national supervisory agencies, ${ }^{79}$ and, in addition, all banks are subject to the Sherman Act and the Clayton Act. ${ }^{80}$

It is clear that the independent status of the state banking systems has been greatly compromised by national policy that either invites or compels subjection to national jurisdiction. The states do not have equality of position in banking regulation. It is obvious, also, that the existence or lack of uniformity in bank supervision, always affected by the existence of a dual banking system, is now primarily dependent upon the degree of coordination among national agencies. ${ }^{81}$.

Whether national policy will further enlarge the national role and correspondingly reduce the state role in banking regulation may be dependent upon a number of factors. Since the national government has already taken steps to preserve solvency for most banks, it may be that considerations of soundness in bank operations will not materially change the balances between national and state authority or affect the dual banking system. A change in the relative strength of competing interests with respect to bank structure such as to result in a national policy on branching and other forms of multiunit banking would reduce the position of the states and set in motion a new chain of effects on dual banking. Similarly, the requirements for

\footnotetext{
75 See p. 758 supra.

70 "It is a strange quirk of history that in 1933 Congress rather inadvertently adopted a measure [deposit insurance] to save a dual banking system that so few thought in need of salvation; and that, by adopting this measure, it paved the way for a 'unified national system' of banking that it was not even striving for." Kent, Dual Banking Between the Two World Wars, in Banking and Monetary Studies 43, 6r (D. Carson ed. I963).

${ }^{77}$ I5 U.S.C. $\$ 78(\mathrm{~g})\left(\mathrm{Ig}_{54}\right)$.

${ }^{78}$ I2 U.S.C.A. $\$ \S 184 \mathrm{I}-49$ (Supp. I966).

${ }^{70}$ I2 U.S.C.A. $\$ 1828$ (c) (Supp. I966).

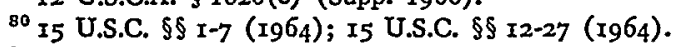

${ }^{8 x}$ See generally Wille, stipra note 34 .
} 
effective monetary policy could alter the balances between national and state supervision. Arguments have, of course, been advanced pro and con on whether stabilization policy and bank supervision should be pursued separately. ${ }^{82}$ The issue has been considered with respect to valuation of bank assets, but it can arise on other matters. Any state authorizations, requirements, or limitations on state banks that impede national stabilization efforts, or any state banking operations that have that effect, may be swept aside by national policy applied uniformly to all banks.

\section{VI}

\section{Current Arguments About the Dual Banking Systems}

As is generally true in arguments about federalistic arrangements for accomplishing a particular governmental function, the arguments on dual banking reflect views both about government in general and about the the particular function, and behind these various views are the interests of groups. There are no organized groups attacking the dual banking system, but it is defended strongly by certain organizations. The chief of these is the National Association of Supervisors of State Banks, the Independent Bankers Association, and the American Bankers Association. Notably, the last of these celebrated in 1963 the one hundredth anniversary of the dual banking system rather than the centennial of the establishment of the national banking system!

The primary argument in favor of the system of dual banking is that it provides flexibility in service of the banking needs of the communities of the nation. The argument has recently been stated by an advisory committee reporting to the New York Superintendent of Banks: $:^{83}$

The dual system fosters innovation by permitting either the state or the Federal governments to experiment with and to develop new approaches to satisfying the banking needs of the public. In a single system, either all state or all federal, innovation and a sensitive response to the changing banking needs of the economy would have been much more difficult.

The committee said that both the state and national systems had contributed innovations that made for progress in banking, but cited particularly state introduction of branching, loans on real estate, and fiduciary operations. ${ }^{84}$

A banker's argument in favor of dual banking is that it prevents overburdensome control. Checks and balances among control agencies-between national and state and among national authorities-preserves a check for the banker against govern-

\footnotetext{
${ }^{82}$ See the replies from the FDIC, state bank supervisors, the Council of Economic Advisers, Federal Reserve Bank Presidents, and the Chairman of the Board of Governors to a question on the role of bank supervision. Staff of Joint Comm. on the Economic Report, 82D Cong., 2p SEss, Monetary Policy and Management of the Public Debt pt. I, at 401-02, pt. II, at 953, 967-73, 875, 703-04 (Comm. Print 1952).

${ }^{83}$ New York Advisory CoMmittee, First Report 2.

s4 Id. at 2-3.
} 
ment. A resolution of the American Bankers Association in 1962 included this: "The checks and balances which are inherent in the dual banking system have served as a deterrent to inappropriate or unduly burdensome actions on either the State or National level."85 Similarly, the New York superintendent's advisory committee recently said, "[T] he dual system imposes upon those responsible for law-making and supervision an attitude of reasonableness and flexibility in the regulation of banks, an attitude that a monolithic system would be less likely to foster." checks and balances is, of course, the freedom of banks to convert from one system to another. Counsel for the Independent Bankers Association has testified that this freedom means that the two levels (national and state) will be cautious about overregulating. ${ }^{87}$

It is argued that diffusion of political power conforms with the traditions of this country and that in economic matters there is greater safety in decisions by many rather than by a few. ${ }^{88}$ Also, the diffusion of regulatory power in the national government is seen to be related to this diffusion between national and state authorities. A member of the Board of Governors has argued that an advantage of the present system of divided jurisdiction at the national level is that it shields states' rights, safeguards the autonomous spheres of national and state regulation, and supports the checks-and-balances principle embedded in the Constitution. ${ }^{89}$ The New York advisory committee called the dual banking system "a species of Federalism, with its attributes of checks and balances and the diffusion of governmental power which has served this country well in preserving the freedom, and in encouraging the initiative and the independence, of its citizens."

The reverse of these several arguments could be found in numerous statements expressing concern about looseness, conflicting standards, and lack of coordination in bank supervision. ${ }^{01}$ The "competition in laxity" resulting from competing jurisdictions has often been cited. Usually this has been attributed to the loosening of national standards to meet lower standards in some of the states, though recently leadership in "liberalization" of standards has come from the Comptroller's office. The competition in laxity is still seen to be a danger, and the difficulties in cooperation and the time spent in liaison and coordination are lamented. ${ }^{92}$ As for the arguments on checks and balances, those who question the divided jurisdiction which

\footnotetext{
so Hearings on Conflict of Federal and State Banking Laws Before the House Comm. on Banking and Currency, 88th Cong., Ist Sess. 4 (1963) (proposal quoted by S. E. Babington, President of the Independent Bankers Association) [hereinafter cited as $196_{3}$ Hearings].

${ }^{86}$ New York Advisory Committee, First Report 3.

${ }^{87}{ }_{196}$ Hearings $7-8$ (statement of Horace R. Hansen).

${ }^{88}$ Id. at 5-6 (statement of Horace R. Hansen).

${ }^{80}$ Hearings, supra note 35 , at I 82 (statement of Abbot L. Mills, Jr.).

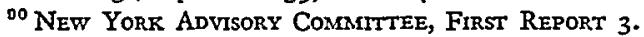

${ }^{01}$ Sec, e.g., Robertson, Federal Regulation of Banking: A Plea for Unification, in this symposium, p. 673 .

${ }^{03}$ Although he was not arguing against dual banking, Chairman Martin commented on time devoted to liaison, cooperation, and negotiation in present bank supervision, in Hearings, supra note 35, at 606-07.
} 
exists would assert (I) the superior constitutional power of the national government and (2) the inappropriateness of using the checks-and-balances thesis as an argument for preserving conflicting administrative jurisdictions and the option of regulated companies to choose the jurisdictions to which they will be subject.

The crucial issue today, in the opinion of the Independent Bankers Association (IBA) and of former Comptroller Saxon, is that of location of decision making on multiunit banking. ${ }^{93}$ Saxon stated his view as follows:

The branching powers of national banks should, in my judgment, not be limited according to those policies which the individual states find appropriate to meet their local needs through state-chartered banks. By the same token, I believe that the state supervisory agencies should be granted the final authority to approve branching by state-chartered banks, whether or not they are members of the Federal Reserve System. ${ }^{94}$

On this issue the IBA states, "It is our conviction that the people in each State must have the ultimate right to decide what kind of banking system is best for them." ${ }^{105}$ Both IBA and Saxon stress the values of competition. The former fears the effect of multiunit banking on "independent" banking, whereas Saxon believes that in certain markets economies of scale better serve the needs of the public. Saxon also points out that many bank services are not dependent on bank size ${ }^{96}$ and contends that therefore unit banks will remain competitive. The standard proposed by Saxon would require unit banks to compete without a shelter for inefficiency. ${ }^{97}$ The IBA claims that it too believes in competition among banks. On the other hand, it has been said that Saxon advances a new concept of competition between systems. ${ }^{\text {98 }}$

The two do argue different concepts of dual banking. Both accept dual chartering and banker option on jurisdiction. The IBA argues, in addition, for a dual banking system characterized by national adoption of state policy. Saxon argues, in contrast, that "the only sense in which the duality of a banking system can be made truly meaningful is to regard the authority of each segment as separate and distinct, and not subordinate one to the other.

Saxon recognizes that the independence of the two systems of bank supervision is weakened by national supervision, as well as by national adoption of or deferral to state policy. His answer is, "I believe, further, that the state supervisory agencies

\footnotetext{
${ }^{98}$ Mr. Saxon's retirement as Comptroller may, of course, mark an end of the controversy, but this seems unlikely even if Saxon's successor follows more conservative policies. The issues having been raised, they will not be allowed to disappear until the critics of the present system are satisfied. See, e.g., Kreps, Modernizing Bank Regulation, in this symposium, p. 648.

${ }^{84}$ Address before the National Ass'n of Supervisors of State Banks, Bretton Woods, N.H., Sept. I8, 1962.

${ }^{26}{ }_{1963}$ Hearings 3 (statement of S. E. Babington).

${ }^{\circ 6}$ Id. at $37 \mathrm{x}-75$.

or Id. at 278 .

${ }^{88}$ Id. at 99 (statement of Randolph Hughes, Chairman, Legislative Committee, National Association of Supervisors of State Banks).

${ }^{\circ 0}$ Address, supra note 94 .
} 
should be encouraged to build adequately-compensated staffs to the point that they may be relied upon to assume full responsibility for the examination and supervision of state-chartered banks." ${ }^{100}$ Those who oppose Saxon are not likely to believe that strengthening of state supervision would eliminate FDIC and Federal Reserve supervision and thus reproduce the independence of the state systems that existed prior to the passage or the acts creating these authorities.

\section{Concuusions}

History, not logic, explains the existence of the dual banking system. It was not planned. It arose because of a change in banking opportunities not foreseen by policy makers in 1863 . It survived because both supervisory jurisdictions responded to the pressures for increased banking facilities. It remains because national policies have been adjusted to the existence of state banks. National policy supports the system by making optional membership in the Federal Reserve System, deference to state policy on branching and in other areas, and the inclusion of state banks in the deposit insurance system.

The system of dual banking that exists is a many-faceted system. It includes dual chartering and separate supervision by chartering jurisdictions, but also features overlapping of the two systems by national adoption for national banks of state policies, on the one hand, and national attraction of state banks into national supervisory systems, on the other. It is the total set of arrangements that determines the nature of the system.

Several general lessons on federalism can be seen in the development of the system. The chances of history affect the allocation of functions between national and state governments. Policy is built incrementally on existing system. Exercise of delegated powers is checked by the strength or weakness of going systems and the interests served by them. The attributes of federalism are determined far less by legalism and principle than by the course of events affecting the performance of a particular function. These attributes will vary function by function and will, both for separate functions and for federalism as a whole, put unplanned and unmatched patches on a multipatterned coat.

Federalism in banking is not constitutional federalism but legislative and administrative federalism resulting from the nonuse of national powers. Its pattern in the future, if it survives, will depend on two things: first, the results of the continuing contest over multiunit versus independent banking; and, second, the extent to which unity in monetary and credit policy is impeded by lack of unity in the banking system. The first of these will determine the survival of the national policy of deferring to state policy choices; the second will dictate the degree of national encirclement of the state regulatory functions.

${ }^{100}$ Id. 
